2019, Vol. 05(1) 91-119

Copyright (C) University of Sri Jayewardenepura

ISSN 2448-9344

ISBN 978-955-23-0019-3

Reprints and permissions:

vjm@sjp.ac.lk

\title{
Infrastructure Investment with Public-Private Partnership (PPP) and Economic Growth in Developing Countries in Asia
}

\author{
P.J. Atapattu \\ Graduate School of International Development \\ Nagoya University
}

\begin{abstract}
Infrastructure is an important factor of economic growth in developing countries, and economic growth is constrained by the inadequacy of infrastructure. The advantage of Public-Private Partnership (PPP) in infrastructure is well recognized, allowing financing for expensive infrastructure investments. This study examines the importance of PPP for infrastructure to economic growth in nine developing countries in Asia. The estimated period is from 1990 to 2015 using panel data with fixed effect. The dependent variable is GDP, and independent variables are PPP infrastructure stock, non-PPP infrastructure stock, labor force and literacy rate as a proxy variable of quality of labor. This study estimates PPP infrastructure stock using the Perpetual Inventory Method and controls for the external effect of the Asian Economic Crisis in 1998.This study finds positive effects of PPP infrastructure stock on economic growth. PPP infrastructure stock is an addition to the existing infrastructure stock. The result of this study encourages more PPP investment in developing countries in Asia for economic growth.
\end{abstract}

\section{Keywords}

Economic Growth, Developing Countries, Infrastructure Stock and PublicPrivate Partnership in Infrastructure

Corresponding Author:

Preethinee Jayanthi Atapattu, Graduate School of International Development, Nagoya University, Furo-Cho, Chikusa - Ku, Nagoya, 464-860I, Japan. E-mail: preethij@iuj.ac.jp 


\section{Introduction}

The importance of infrastructure to economic growth is well captured in Sustainable Development Goal 9 - Industry, Innovation, and Infrastructure, Goal 6 - Clean water and sanitation, Goal 7 - Affordable and clean energy, and Goal 11-Sustainable cities and communication (UNDP, 2012). Infrastructure ${ }^{1}$ has been identified as one of the key factors contributing to achieving economic growth in developing countries (World Bank, 1994:14) at the early stage of the discussion and later in (Trebilcock \& Rosenstock, 2013:3) and (Straub, 2010:3).

Characteristically, infrastructure is different from other types of goods in terms of supply, demand, availability, consumption, and longevity. Infrastructure is traditionally financed, built and maintained by governments as a part of investment spending and it is publicly funded due to two main reasons (Duffy-Deno, 1989:329; World Bank, 2016:4). The first reason is that expenditure for infrastructure is high and consumes a long time for construction. The second reason is that infrastructure building involves economies of scale. However, infrastructure demonstrates the feature of being public good, as consumption cannot be controlled for once the infrastructure is provided. The provisioning and locating of infrastructure are publicly decided, and the public involvement can be seen in terms of payment (e.g. taxes, tolls). Both households and the business sector consume and demand infrastructure, despite the considerably long time required for its construction.

Infrastructure spending is important as infrastructure serves as a growthenhancing factor linking with productivity and efficiency and less investment in infrastructure is a bottleneck to economic growth in developing countries (IMF, 2014). These countries face difficulties in financing huge and expensive infrastructure investments as a result of lack of investment, which is an inherent constraint. At this point, the use of public-private partnership ${ }^{2}$ (PPP) is a viable alternative source of finance to fill the gap in infrastructure investment. Private

\footnotetext{
1"Infrastructure includes all public services from law and order through education and public health to transportation, communication, power, water supply as well as agricultural overhead capital as irrigation and drainage systems" (Hirschman, 1958).

2 "Public-Private Partnership refers to a contractual arrangement between public and private entities through which the skills, assets and /or financial resources each of the public and the private sectors are allocated in a complementary manner thereby sharing risk and rewards, to seek to provide optimal service delivery and good value to the citizens." (ADB, 2012)
} 
sector financing in the infrastructure is technically referred to as private participation in infrastructure (PPI).

Figure 1 is the graphical representation of PPP infrastructure stock as a percentage of the capital stock from 2000 - 2015. PPP infrastructure stock tends to increase in sample countries except for India, Indonesia, Malaysia, and Thailand. The highest growth rate is reported in Sri Lanka as the country started an infrastructure led growth strategy as a post-war development plan. PPP is beneficial as it lessens fiscal constraints and allows risk sharing. Developing countries use PPP as an alternative source of financing as developing countries' governments alone face difficulties in financing huge investments.

This paper aims to estimate the contribution of PPP infrastructure stock to economic growth in a sample of nine developing countries in Asia. This study is from 1990-2015, according to the World Bank classification of 2017 using balanced panel data (Appendix 1A). A noteworthy gap in the previous literature is that the quantitative impact of PPP infrastructure on growth has not been "systematically analyzed," and the positive economic impact is mainly analyzed using case studies (World Bank, 2016:4). The main contribution of this paper involves addressing this gap in the previous literature by estimating the contribution of PPP investment quantitatively in infrastructure.

Figure 1: PPP Infrastructure Stock as a percentage of Capital stock (20002015)

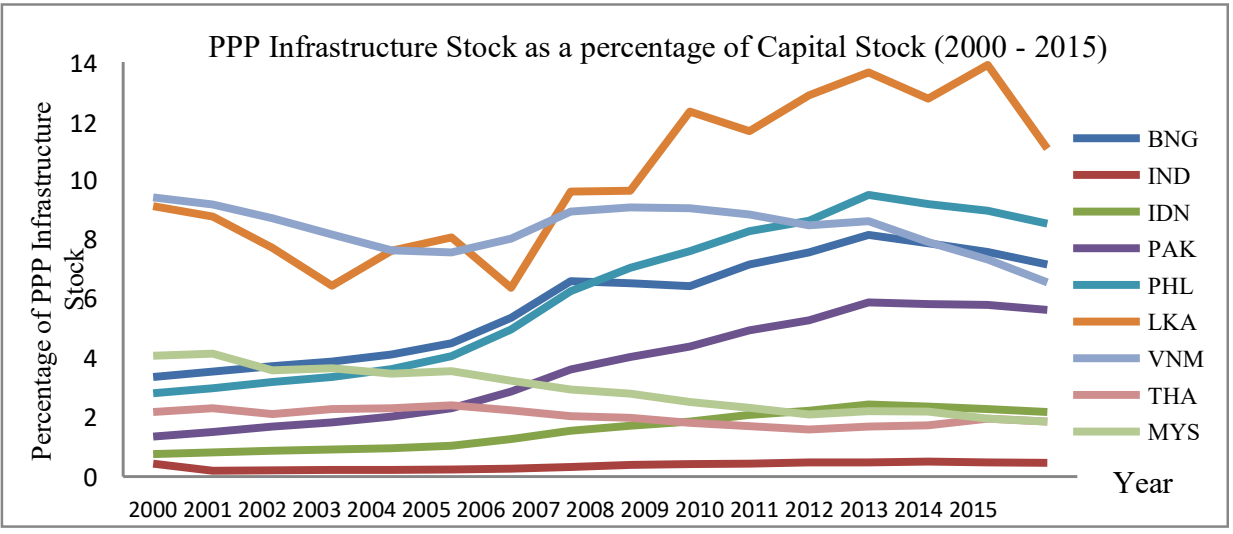

Data: IMF capital and Investment Data Set and World Development Indicators 
Infrastructure growth literature often argues the inappropriateness of the flow concept and prefers stock concept (Blanca, 1998) and (Calderón, 2004). Thus, this paper estimates a series of PPP infrastructure stocks from 1990-2015 while considering country-specific depreciation rates, as depreciation is very important regarding infrastructure stock that is subject to decay. The sample countries in the study are Bangladesh, India, Indonesia, Malaysia, Pakistan, Philippines, Sri Lanka, Thailand, and Vietnam. The results indicate PPP investment contributes positively to economic growth in developing countries in Asia.

The study is organized as follows. Section 1 is the Introduction, and Section 2 represents the Literature Review while Section 3 deals with Methodology and Data Analyses. Results will be discussed in Section 4 and the Conclusion of the study will be presented in Section 5 .

Column A and B of Table 1are the estimated infrastructure needs in the sample countries from 2010-2020 using the "bottom-up approach" adopted by (Bhattacharyya 2010:12). Column C and D are PPP infrastructure stock as a percentage of infrastructure needs in 2010 and 2015. Percentage of PPP infrastructure stock is varied among countries and years. The highest percentage is in 2010 is from India while the lowest is from Malaysia. The Philippines reported the highest percentage in 2015. Sri Lanka and Vietnam report zero percentage in 2015 as no PPP infrastructure is made in the particular year. PPP infrastructure investment helps to reduce the amount of required infrastructure. Financing infrastructure requirement is a challenge as developing countries stuck into structural bottlenecks.

Table1. National Infrastructure Needs in Sample Countries (2010-2020) of this Study

(US\$, 2008 Millions)

\begin{tabular}{lrrrr}
\hline Country & $\begin{array}{r}\text { Estimated } \\
\text { Infrastructure } \\
\text { needs }\end{array}$ & $\begin{array}{r}\text { Total } \\
\text { Investment } \\
\text { needed } \\
\text { Per year }\end{array}$ & $\begin{array}{r}\text { PPP as a \% } \\
\text { of Total } \\
\text { Investment } \\
\text { Needed }\end{array}$ & $\begin{array}{r}\text { PPP as a } \\
\text { Investment } \\
\text { Needed }\end{array}$ \\
& $(\mathrm{A})$ & $(\mathrm{B})$ & $(2010)(\mathrm{C})$ & $(2015)(\mathrm{D})$ \\
\hline Bangladesh & 144,903 & 13,173 & 5.7 & 3.7 \\
India & $2,172,469$ & 197,497 & 44.0 & 3.9 \\
Indonesia & 450,304 & 40,937 & 11.5 & 0.7 \\
Malaysia & 188,084 & 17,099 & 3.0 & 30.3 \\
\hline
\end{tabular}


INFRASTRUCTURE INVESTMENT WITH PUBLIC-PRIVATE PARTNERSHIP (PPP) AND ECONOMIC GROWTH IN DEVELOPING COUNTRIES IN ASIA

\begin{tabular}{lrrrr}
\hline Pakistan & 178,558 & 16,233 & 13.3 & 3.3 \\
Philippines & 127,112 & 11,557 & 25.8 & 59.7 \\
Sri Lanka & 37,908 & 3,446 & 9.0 & 0 \\
Vietnam & 109,761 & 9,978 & 35.0 & 0 \\
Thailand & 172,907 & 15,719 & 4.9 & 15.9 \\
\hline
\end{tabular}

Note: Column A and B are adopted from (Bhattacharyya 2010:12).

Columns $\mathrm{C}$ and D are the PPP infrastructure investment as a percentage of column B, calculated by the author.

\section{Literature Review}

Theoretically, infrastructure plays a key role in achieving economic growth. Rostow (1959) links the development of social overhead capital as a precondition for the "take-off stage" of economic growth. At this stage, Rostow focuses on the importance of transport and power sectors and skilled labor force. Social overhead capital according to Rodan (1994:214) is " transport, power, and water supply, which are basic for any productive activity, cannot be imported from abroad, required large and costly installations" where he considered investment in these sectors as complementary to increase production. Development of these sectors provides the phase for the expansion of economic activities providing preconditions for an economy to take off" (Rostow, 1959). Infrastructure investment provides a positive relationship with economic growth, as found in the literature (Aschauer, 1989; Sahoo \& Dash, 2012). Developing countries have to sacrifice economic growth due to insufficient investment in infrastructure. Thus, PPP investment in infrastructure has become a promising tool to finance infrastructure in developing countries since 1990s.

The main advantage of PPP in infrastructure is "mobilizing additional finance for infrastructure and differ the payment for the future" (World Bank., 2016:4), and the importance of PPP in infrastructure is discussed in terms of accessing economic growth, equal distribution of income, reducing unemployment and poverty reduction. Nishizawa explores the importance of PPP in Asia as an alternative to public investments and finds successfulness depends on unique characteristics to each country (Nishizawa, 2018). Meeting infrastructure demand challenges and utilizing PPP as an option has proven to lead to increased efficiency gains (Trebilcock \& Rosenstock., 2013). PPP is a 
growth-promising factor in India, and the impact of PPP investment leads to skill development in the labor force and increase in efficiency leading to economic growth (Biswas, 2016). Reddy (2015) assesses the prominence of PPP investment in India in terms of releasing budgetary constraints and employment creation and finds a positive effect of PPP investment on GDP growth. PPP investment in infrastructure appears to be an important component of total infrastructure investment for a country. Estache (2014:9) recommends the importance of econometric evaluation of PPP and a "careful choice of control variables" to fill up the gap in the literature related to PPP infrastructure. Labor is the driving force of the economy determining the economy's production capacity apart from the capital. Solow growth model explains the importance of labor and capital achieving in long-run economic growth. Romer (1987) finds labor as a driving source of economic growth and Bloom (2010) identifies the low productivity of labor in developing countries as a significant constraint to economic growth. Skills of the labor force are termed as the quality of the labor. Importance of labor quality and economic growth are reinforcing each other as disclosed by (Hanushek \& Kim., 1995). Quality of the labor is proxied by literacy rate as finds in literature. The positive relationship between literacy rate and economic growth is consistent in the literature (Barro, 1991) (Mankiw, 1992). Capital stock, which refers to the government-owned assets (Aschauer, 1989; Munnell, 1990), also positively contributes to economic growth (Flores de Frutos, 1998; O'Fallon, 2003). Furthermore, the productivity of a country's production changes according to the composition of the capital stock (Chen, 1997). Electricity has proven to have a significant favorable impact on the production process and the livelihood of rural people while contributing to uses of the machines allows greater productivity and to lighting purposes and (Jerome, 2012). Telephone infrastructure and economic growth have a positive relationship (Sridhar, 2008) and reduce the fixed cost of obtaining information (Norton, 1992). Transportation and water and sanitary infrastructure are also known to improve productivity. Theoretically, a reduction of the transport cost increases accessibility, which is considered as "primary benefit" of transport. Chandra (2000) studied large infrastructure spending on highways and found positive effect of increased investment. Likewise, improved water access and sanitation positively contribute to economic growth, while a lack of clean water and sanitation is a barrier to economic growth (CSD, 2004; Frontier Economics, 2012).

Of note, sample countries in the present study were significantly damaged by the headwinds of Asian financial crisis of 1998, especially Indonesia, 
Malaysia, the Philippines, and Thailand, where infrastructure investment was dramatically reduced (Bhattacharyay, 2010). The global financial crisis of 2008 is another noteworthy economic turmoil that occurred during the sample period (Appendix 1B). Accordingly, the literature in PPP is limited and the outcome based on "anecdotal evidence and case studies" and "comparison of outcomes" (World Bank, 2016:4). The report concludes by questioning the robustness of the results as studies based on case studies: "Unfortunately, the overall economic impact of PPP has not been systematically analyzed using robust and sound analysis" (World Bank, 2016:4). This paper attempts to fill the gap in the literature in terms of systemically analyzing impact of PPP investment into economic growth. This paper is important in three ways; In terms of (i) documents PPP stock infrastructure (ii) estimates PPP infrastructure stock, and (iii) estimates the contribution of PPP infrastructure and non-PPP infrastructure stock separately to economic growth in the sample countries. Figure 2 is the conceptual framework of the study.

\section{Figure 2: Conceptual Framework}

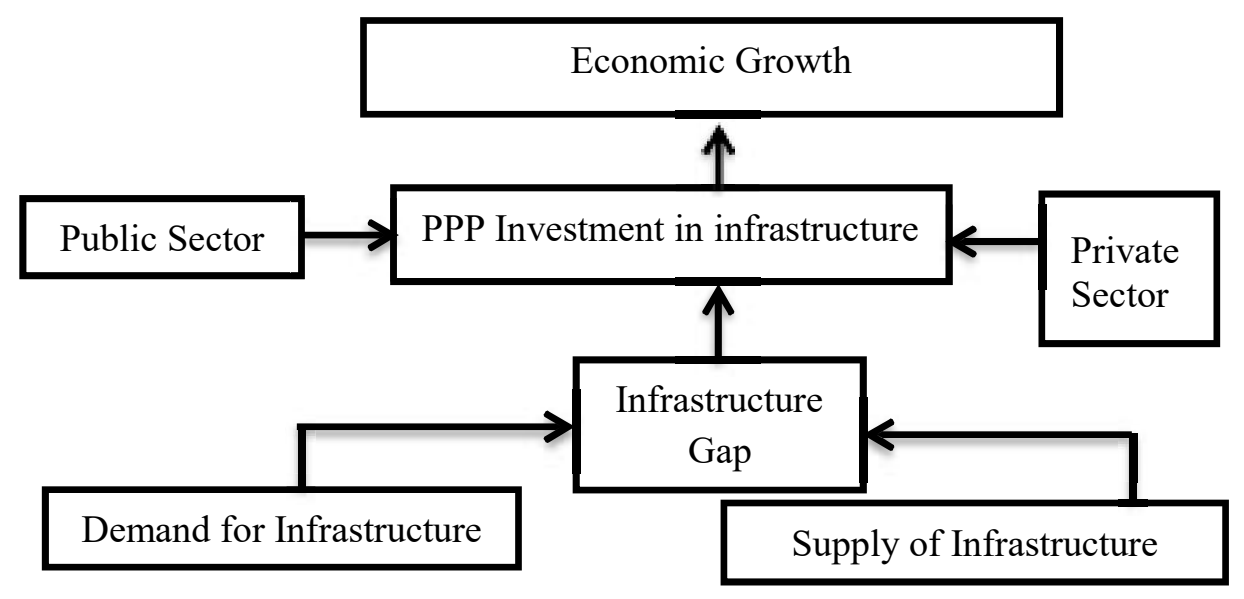




\section{Methodology and Data}

\section{Estimation of Infrastructure Stock with PPP}

This section is devoted for estimating infrastructure stock with PPP. To estimate infrastructure stock with PPP in the sample countries, the researcher has to estimate initial infrastructure stock of the base year. The base year for the paper is 1990, as the investment in infrastructure PPP starts in 1990 according to World Bank data ${ }^{3}$. The researcher builds upon the methodology of (Nehru \& Dareshwar., 1993) to estimate the initial infrastructure stock of the base year. Nehru and Dhareshwhar (1993) estimated the capital stock for 92 countries from 1960-1990 where they utilized the "modified Harberger approach".

The Perpetual Inventory Method (PIM) interprets the capital stock of the economy in terms of an inventory which increases according to capital formation, and it is prioritized among numerous researchers for generating capital stock data (Berlemann, 2014; Nehru \& Dareshwar, 1993), the function of the PIM is to interpret capital stock of the economy as an inventory. One main characteristic of capital stock is the tendency to depreciate over time the stock of capital tends to depreciate but never becomes zero, revealing the appropriateness of its perpetual use. This study utilizes country-specific depreciation rates following (Feenstra \& R Inklaar, 2015). Infrastructure stock is expected to decrease over time as it is utilized, and this is termed as depreciation. The net infrastructure stock of the economy $K_{t}$ can be written as a function of the net infrastructure stock at the beginning of the period. $K_{t-1}$ is the gross investment in the beginning of the period, $I_{t}$ is the investment of the beginning of the period and consumption of the infrastructure stock is $I_{t}-D_{t-1}$.

$$
K_{t}=K_{t-1}+I_{t}-D_{t-1}
$$

The modified Harberger approach assumes "the capital-output ratio is constant in a given period, the rate of growth of capital and output are equal during the period" (Nehru \& Dareshwar,1993:43). Equation (1) is calculated based on this assumption.

$$
\frac{\left(K_{t}-K_{t-1}\right)}{K_{t-1}}=-\delta+\left(\frac{I_{t}}{K_{t-1}}\right)
$$

\footnotetext{
${ }^{3}$ for PPP infrastructure starts for the year 1990.
} 
According to the assumptions, output growth rate $\left(g_{G D P}\right)$ and growth of capital or capital stock $\left(g_{k}\right)$ grows at the same rate. Therefore, the output growth of the economy can be written as follows.

$g_{G D P}=g_{k}=\frac{\left(K_{t}-K_{t-1}\right)}{K_{t-1}}=-\delta+\left(\frac{I_{t}}{K_{t-1}}\right.$

The stock of infrastructure for the period of $(t)$ can be written by using equation (2) as follows.

$K_{t}=I_{t-1} /\left(g_{t-1}+\delta_{t-1}\right)$

Related to this point Nehru \& Dareshwar, (1993) found a negative output in their results by solving equation (3) and followed the modified Harberger approach (1978) by introducing a "log of investment against time" (Nehru and Dareshwar 1993:43). Following (Nehru \& Dareshwar., 1993) this paper calculated the log of investment against time and obtained the fitted values. The fitted values are in the $\log$ form and are then transformed into the level form (Appendix 2). By using equation (3), this study calculates the initial capital stock for the base year 1990. Sample countries are separated into two subgroups as upper middle-income countries and lower middle-income countries following (World Bank, 2017 June) at this stage.

\section{Estimation of the Initial Infrastructure Investment for the Base Year}

To calculate the total investment in infrastructure, the researcher added investment in telecoms, investment in energy, investment in transport and investment in water and sanitation. Many researchers recommended telecom, energy, transport and water and sanitation and termed as growth enhancing infrastructure variables (Andres, 2016; Chaplin, 1999; Chen, 2009; Canning \& Pedroni, 2004). At this point, the researcher used only available data and did not treat missing data. The investment in infrastructure data available in current USD was converted into international dollars using 2011 purchasing power parity. By following (Nehru \& Dareshwar., 1993) the researcher estimated the linear regression of $\log$ of investment against time. I then generated the log of investment against time country wise as in equation (4).

$\log \operatorname{INFl}_{t}=\left(y_{1} y_{2} \ldots y_{i}\right)$ 
The fitted values obtained are considered as the initial level of infrastructure investment. By using equation (4); I estimated the country-specific initial stock of PPP infrastructure.

$K_{t}=(1-\varphi)^{t} K(0)+\sum_{i=0}^{t-1} I_{t-1}(I-\varphi)^{i}$

$K(0)$ is the initial infrastructure stock and $\varphi$ is the rate of geometric decay where (Nehru \& Dareshwar, 1993) use a geometric decay rate. This paper uses actual country-specific depreciation rate. By using country-specific investment data, initial infrastructure investment data, and depreciation data, the researcher estimated the equation (5). The estimated stock of PPP investment stock was used to estimate the Cobb Douglas production function.

\section{Method}

The paper explores how infrastructure stock with PPP affects economic growth in developing countries in Asia. Infrastructure growth is mainly estimated using the production function approach, apart from the cost and profit function approach, cross-sectional data regression, and vector auto regression. The production function approach is strong enough to measure infrastructure growth, as found by A Schauer (1990a) and Canning \& Pedroni, (2004) as parameters are robust and clear in the economic sense. Gross Domestic Product (GDP) is the explanatory variable, and the production function is as below,

$Y_{t}=A_{t} K_{t}^{\alpha} L^{\beta}$

Where $\mathrm{Y}$ is GDP, $\mathrm{A}$ is technological process, $\mathrm{K}$ is capital stock, $\mathrm{L}$ is labor force and $\alpha+\beta=1$ assuming constant returns to scale. $\mathrm{K}$, the capital stock, is a combination of PPP infrastructure stock (INFP) and infrastructure stock without PPP (INFN). The purpose of this paper is to measure the contribution of PPP infrastructure stock using PPP infrastructure augmented framework. Therefore, this paper disaggregates capital stock in terms of PPP infrastructure stock (INFP) and infrastructure stock without PPP (INFN) can be written as,

$Y_{t}=A_{t} I N F P_{t}^{\beta 1} I N F N_{t}^{\beta 2} L_{t}^{\beta 3}$

Rewriting equation (6) logarithmically, $\ln \mathrm{A}=\mathrm{a}+\mathrm{b}_{\mathrm{t}}$,

$y_{t}=a+b_{t}+\beta_{1} i n f p_{t}+\beta_{2} i n f n_{t}+\beta_{3} l_{3}$ 
Infrastructure investment during the sample period had to face headwinds sprung by the world economic turmoil of the Asian Economic crisis in 1998 and the Global Finance Crisis 2009. Year dummy variables are applied to control effects of the external shocks, and the equation (9) can be written as using dummies.

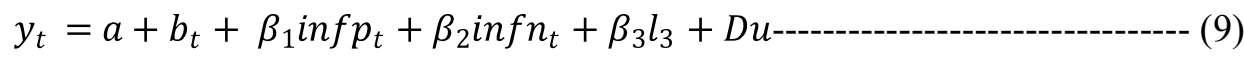

Equation (9) estimates the contribution of the PPP infrastructure stock to economic growth. This study improves upon the methodology of Lan, Chen, and Lim (2016), while the selection of PPP infrastructure variables is developed upon the work of Agenor, (2005) prioritizing telecommunication, electricity power generation, transport, water, and sanitation as infrastructure variables. Ordinary least square (OLS) is recognized as a solution as parameters of $\beta$ explain the average unit change in a dependent variable while controlling other explanatory variables. The model is estimated using both fixed effects (FE) and random effects (RE) where the fixed effects control specific individual effects and the latter assumes individual constant terms are distributed randomly. FE removes time-invariant effects and the estimated results are net effects while the model controls for correlations of the predictors within the country. Countryspecific effects are unique and time-invariant and should be uncorrelated with other country specific effects. The researcher believes the use of FE to estimate the model is practical, as the generated results are not subject to bias. In the FE models, time-specific effects are fixed by intersecting. The RE models, in contrast, assume time specific and country-specific variations are random and uncorrelated to the independent variables. The Hausman test is conducted to select a better model, and the test favored fixed effects. The Hausman test estimates the correlation between the error term and the regressors. Equation (9) is tested under three models. In the first model, all countries (AC) in the sample are used, while in the second model lower middle-income countries (LMI), and in the third model upper middle-income countries (UMI), are used. In the sample of UMI, the sample size is small, and the number of years is large. The fixed effect model is recommended by Gujarati (2011:291) when the sample size is smaller than the number of years. I estimated the contribution of infrastructure to economic growth and found infrastructure stock is significant to economic growth. Then, I re-estimated the equation separating PPP infrastructure stock, as my interest is to observe the contribution of PPP infrastructure stock to economic growth. The model was estimated using 
dummy variables for both the Asian financial crisis (DU98) and Global economic crisis in 2008(DU08).

Equation (9) is estimated using the GMM technique as the model fixes high correlations among independent variables, which is common in panel data (Appendix 5). The GMM technique is well ahead of others as the system treats unobservable parameters assigning probabilities to each point and by providing instruments, and it removes the bias of endogeneity. However, the researcher did not apply the GMM technique as the sample size is small, and the GMM technique is not suitable to employ on small sample sizes as found by Wooldridge, (2001). Stationarity was tested as the first step as proposed by Im, Pesaran and Shin (2003) and all the variables were found to be stationary at first difference while infrastructure stock without PPP is stationary at level form (Appendix 6). The results of the lag selection criteria are suggested two lags according to Schwarz information criterion and the model used maximum two lags. Controlling for non-stationarity in regression is important as it affects the behavior of the regression by adding spurious effect while providing unreliable values for the t-ratio. Studies of Levin and Lin (LL test; 1992, 1993), and Im, Pesaran, and Shin (2003) incorporate the cross-section independence of panel data where the LL test assumes panel data on homogeneous cross sections and later deals with the heterogeneous cross sections. The panel cointegration test is developed to detect long-term relationships among the variables (Appendix 7). Cointegration can be removed by dividing the panel data into sub- panels Kao \& Chiang, (2000) and by using the vector auto regression (VAR) model as shown by (Breitung, 2005). Pedoroni and Kao cointegration tests were conducted and results accept the null hypothesis denoting no cointegration in the long term. The VAR model is used to investigate the short- and long-term causality behavior of the variables (Appendix 8). The results generated by the model are either short-term causal relationships or long-term cointegration relationships. The probability corresponding with each coefficient denotes that the significance and probabilities are greater than the 0.05 level. Therefore, the Wald test is conducted to investigate joint causality of dependent variables, and the probabilities of the Wald test is higher than 0.05. Infrastructure contributes the economic growth by increasing productivity and improving the quality of human capital. The link between infrastructure and economic growth is longterm process. The VAR model captures long term causal relationship based on past years of data. Therefore, the VAR model is not taken into account as an estimation method in this paper. Literature related to VAR pronounces the drawbacks of the model in terms of having several methodological limitations 
(Kust, 2007; Stock \& Watson, 2001), such as consideration of variables. The objective of the research is to measure the contribution of infrastructure to economic growth. Thus, at this point, researcher utilizes OLS.

Of note, China is a developing country in Asia rich with data. However, I omit China from the sample due to its unique infrastructure investment pattern, which is extremely high in comparison to the other sample countries.

\section{Data}

The data set is from 1990-2015 for nine developing countries in Asia. GDP is measured in constant PPP (2011) International Dollars, Investment in energy, Telecommunication, transport, water and sanitation with private Participation (current USD) from World Bank, Private Participation in Infrastructure Project Database. Capital stock is represented by constant international Dollars (PPP 2011) obtained from IMF capital and Investment Data Set. Total labor force is from the International Labor Organization, ILOSTAT database. Literacy rate data is from the UNESCO Institute for Statistics, and the depreciation rate is from (Feenstra \& R Inklaar, 2015).

\section{Results and Discussion}

The dependent variable of the study is GDP. INFP, LAB, LIT and INFN are independent variables whereas all the values are in millions of constant International Dollars (INTD) except LAB and LIT. LAB is in millions and LIT is in percentage. Table 2 shows the summary statistics. The highest value of GDP is 12.88 , and the lowest is 10.8 . The median of INFP is 3.86 and the highest is 4.35 . The mean value of LAB is 7.62 , and the maximum value of LIT is 1.98. The maximum value of INFN is 6.66 and the minimum is 4.38 . 
Table 2--Summary Statistics

\begin{tabular}{lcccll}
\hline Description & GDP & INFP & LAB & LIT & INFN \\
\hline Mean & 11.71 & 3.61 & 7.62 & 1.87 & 5.40 \\
Median & 11.67 & 3.86 & 7.60 & 1.95 & 5.39 \\
Maximum & 12.88 & 4.35 & 8.71 & 1.98 & 6.66 \\
Minimum & 10.8 & 0 & 6.85 & 1.54 & 4.38 \\
\hline
\end{tabular}

Note: Source and definition is reported in appendix 4

Source: Author

Table 3 represents the results in both fixed effect models and random effect models. The sample is split into three subgroups and specification is tested in for each model with the dummy and without dummy variables. The result of the specification with dummy variable is used to result discussion. The key variable of the study is PPP infrastructure stock; it is significant in all samples of developing countries in Asia (AC) at $0.06 \%$, lower income developing countries (LMI) at $0.04 \%$ and upper middle-income developing countries (UMI) at $0.02 \%$, respectively. The results suggest that a $1 \%$ increase in PPP infrastructure stock results in increase in GDP of $0.06 \%$ in AC while $0.04 \%$ for the LMI and $0.02 \%$ for the UMI. The GDP growth resulting from increasing PPP infrastructure stock ranges from $0.02 \%$ to $0.06 \%$ from 1990 to 2015 in developing countries in Asia. The finding keeps consistency with Zangoueinezhad, (2014). Infrastructure stock without PPP generates significant positive results, suggesting a $1 \%$ increase in infrastructure stock generates GDP growth ranging from $0.37 \%, 0.35 \%$ and $0.37 \%$ in $\mathrm{AC}$, LMI, and UMI respectively. 


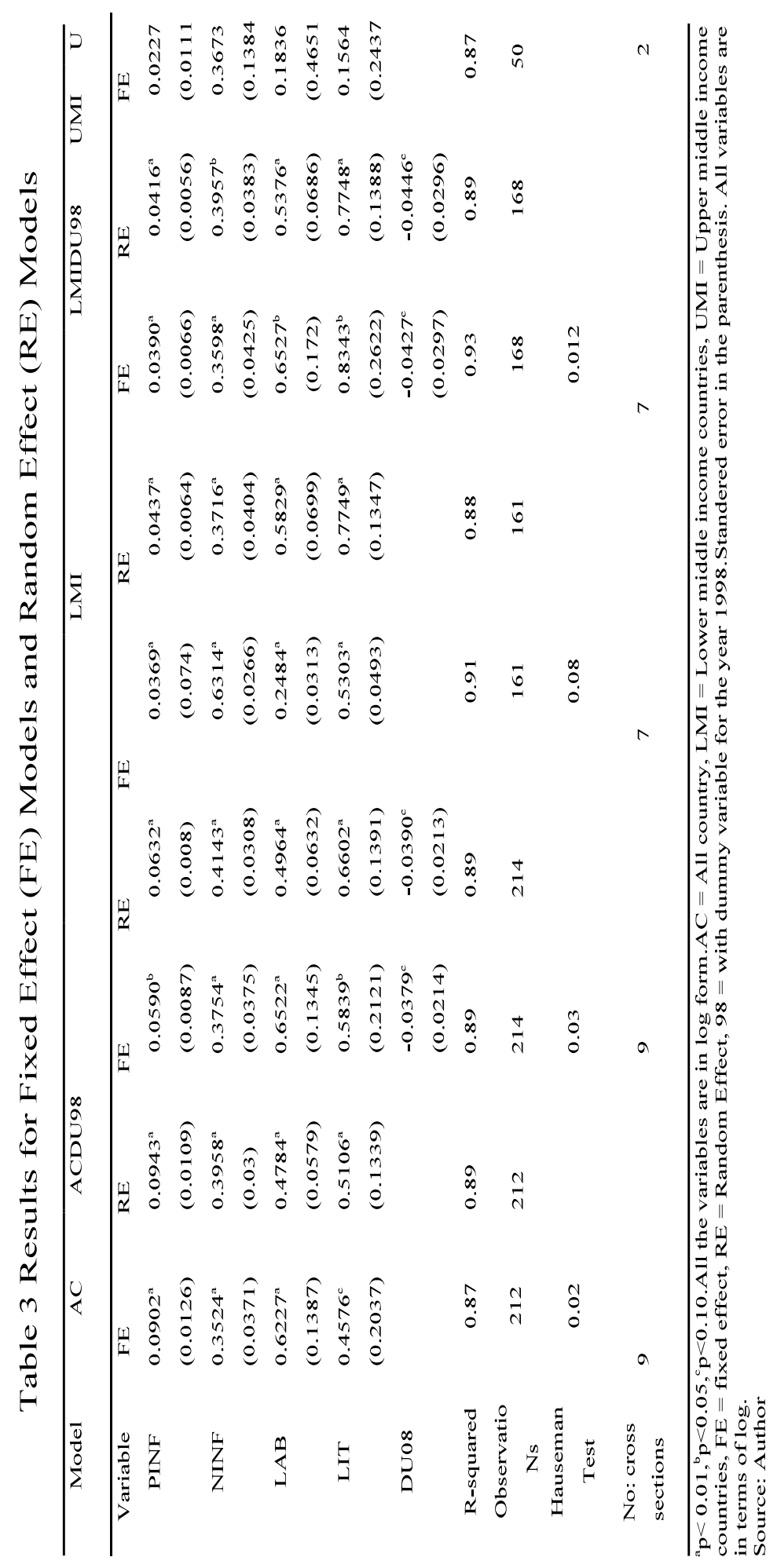


The finding is similar to Sahoo \& Das (2012) and the coefficient is larger than their findings. The GDP growth generated by INFN greater than that generated by INFP, as INFP is comparatively small and subjected to the country, time and sector-specific limitations (Nishizawa, 2018). INFP is an addition to the infrastructure stock of a country, which has a positive effect of increasing economic growth. The impacts of labor and literacy rate are also significant. DU98 is to control the effect of Asian Economic Crisis significant with the expected sign denoting Asian Economic Crisis threated the GDP growth while DU08 controls for Global Financial Crisis in 2008. DU08 is not significant. To save space only significant results are reported.

Overall results suggest INFP is important to economic growth. INFN, LAB and LIT also contribute to achieving economic growth in developing countries in Asia. The contribution of INFP is comparatively high in LMI countries. This can be interpreted as the requirement of infrastructure needs in LMI countries are proportionately higher than that of UMI, which can be identified as a constraint to economic growth. The robust tests are important to assess the stability of the model, therefore the robustness is checked by using robust least squares M-estimation, as reference to the "baseline model and its estimated effect size" (Plumper \& Neumayar, 2016,10). The results find no variation between the coefficients of the baseline model (Table 9); the results of robust test reported only the models of results discussion to save space.

\section{Conclusion}

This paper investigates the role of INFP in accelerating economic growth in developing countries in Asia by using panel data from 1990to 2015. Most of the previous studies related to PPP infrastructure were case studies yet the literature recommends econometric analysis for overcoming several limitations. This study combines PPP investments under four major categories of energy, telecommunication, transport and water and sanitation to estimate PPP infrastructure stock using the perpetual inventory method.

The Asian Financial Crisis in 1998 and Global Economic Crisis in 2009 retarded economic growth and reduced investments. The Asian financial Crisis badly affected the sampled countries. The paper controls the external shocks and finds the positive contribution of PPP infrastructure stock, infrastructure stock without PPP and labor force to economic growth using fixed effects models. LMI demands more infrastructure investment in comparison to UMI, 
showing a wide infrastructure gap. These countries face budgetary constraints in financing infrastructure gap and PPP investment is the best option. The PPP infrastructure stock has a significant impact on the economic growth of the sample countries. The results of the model speak to the value of increasing PPP investment in infrastructure in developing countries and promoting endogenous growth along with skilled labor through infrastructure augmented economic growth model. This finding is important in policy concern and is consistent with the current discussion regarding the development policies of SDGs. For future research, I suggest increasing the sample size and consider the quality of infrastructure to better capture the results and encourage applying a GMM model when dealing with the larger sample size. Further, quality of the institution affects the PPP infrastructure investment, which is not touched on this paper. In future research it is encouraged to consider the quality of the institution as well.

\section{References}

ADB, A.D.B., 2012. Public-private partnership operational plan 2012-2020: Realizing the vision for Strategy 2020. Mandaluyong City: Asian Development Bank.

Agénor, P.-R., Nabli, M.K., Yousef, T.M. \&., 2005. Public Infrastructure and Private Investment in the Middle East and North Africa. Policy Research Working Paper; No. 3661. World Bank, Washington, DC.

Agénor, P.-R., Nabli, M.K. \& Yousef, T.M., 2007. Public Infrastructure and private investment in the middle east and the North America. Breaking the Barriers to Higher Economic growth, pp.399-422.

Andres, A.L., 2016. A Methodological Framework for Prioritizing Infrastructure Investment. World Bank Policy Research Paper. 
Aschauer, D.A., 1989. Is public expenditure productive? Journal of monetary economics, pp.23(2), 177-200.

Bank, W., n.d. 2016:3.

Barro, R.J., 1991. Economic growth in a cross section of countries. The quarterly journal of economics, pp.106(2), 407-443.

Bhattacharyay, B.N., 2010:11. Estimating Demand for Infrastructure in Energy, Transport, Telecommunications, Water and Sanitation in Asia and the Pacific:2010-2020. Tokyo: ADBI Institute.

Biswas, W., 2016. Public private partnership and economic growth with special reference to india - an Overview. International Journal of Management, pp.18-26.

Blanca, S.R., 1998. Infrastructure investment and growth: Some empirical evidence. Contemporary Economic Policy, pp.98-108.

Bloom, D.E \&.Y.W., 2010. The contribution of population health and demographic change to economic growth in China and India. Journal of Comparative Economics, pp.38(1), 17-33.

Breitung, J..\&.D.S., 2005. Panel unit root tests under cross-sectional dependence. Statistica Neerlandica, 59(4), pp.414-33.

Calderón, C..\&.S.L., 2004. The effects of infrastructure development on growth and income distribution. The World Bank.

Canning, D., 1998. A Database of World Infrastructure Stocks, 1950-1995. World Bank Economic Review, pp.529-47.

Canning, D. \& Pedroni, P., 2004. The Effect of Infrastructure on Long Run Economic Growth. Department of Economics Working Papers 2004-04.

Chandra, A., 2000. Does public infrastructure affect economic activity?: Evidence from the rural interstate highway system. Regional Science and Urban Economics, pp.457-90.

Chaplin, S.E., 1999. Cities, sewers and sanitation. Environment and Urbanization, pp.145-58. 
INFRASTRUCTURE INVESTMENT WITH PUBLIC-PRIVATE PARTNERSHIP (PPP) AND ECONOMIC GROWTH IN DEVELOPING COUNTRIES IN ASIA

Chen, E.K., 1997. The total factor productivity debate: determinants of economic growth in East Asia. Asian-Pacific Economic Literature, 11(1), pp.18-38.

Chen, Z., 2009. Modeling flood induced interdependencies among hydroelectricity generating infrastructures. Journal of Environmental Management 90(11).

CSD, 2004. Making water a part of Development. Norway and Sweden Government.

Duffy-Deno, K.T..\&.E.R.W., 1989:329. Public infrastructure and regional economic development: a simultaneous equations approach. Federal Reserve Bank of Cleveland, Research Department.

Economics, F., 2012. Exploring the links between water and economic growth. A report prepared for HSBC by Frontier Economics.

Estache, A..\&.S.S., 2014:9. Public-private partnerships and efficiency: A short assessment. CESifo DICE Report, pp.12(3), 8-13.

Feenstra, R.C..I.R..\&.T.M.P., 2015. The next generation of the Penn World Table. American economic review, 105(10), pp.3150-82.

Feenstra, R. \& R Inklaar, M.T., 2015. The next generation of the Penn World Table. American economic review.

Flores de Frutos, R..G.-D.M..\&.P.T., 1998. Public capital stock and economic growth: an analysis of the Spanish economy. Applied Economics, pp.985-94.

Gujarati, D.N., 2011. Basic Econometrics.

Hanushek, E.A. \& Kim., D., 1995. Schooling, labor Force quality and Economic growth. National Beureau of Economic Growth.

Hirschman, A.O., 1958. The Strategy of Economic Development. Yale University Press.

ILO, 2017. Asia-Pacific Labour Market Update. ILO Regional Office for Asia and the Pacific. 
IMF, 2014. Is it time for an infrastructure Push? The Macro Economic effects of public Investment. International Monetary Fund, pp.75-114.

Jerome, A., 2012. Infrastructure, Economic Growth and Poverty Reduction in Africa. Journal of Infrastructure Development, pp.127-151.

Kao, C. \& Chiang, M.H., 2000. On the estimation and inference of a cointegrated regression in panel data. Advances of Econometrics 15, pp.7-51.

Kust, R.M., 2007. Vector Auto regression.

Lan, X.M., Chen, O.B. \& Lim, K.S., 2016. The Infrastructure Development in the Republic of Guinea. Athens Journal of Business and Economics, pp.277-90.

Mankiw, N.G..R.D .\&.W.D.N., 1992. A contribution to the empirics of economic growth. The quarterly journal of economics, pp.107(2), 407437.

Munnell, A.H., 1990. Why has productivity growth declined? Productivity and public investment. New England economic review, (Jan), pp.3-22.

Nehru, V. \& Dareshwar., A., 1993. A new database on physical capitalnstock:sources, Methodology and results. Revista de analesis Economico, 8(1), pp.37-59.

Nishizawa, T., 2018. Infrastructure Investment and Finance in Asia. Public Policy Review, pp.925-54.

Norton, S.W., 1992. Transaction costs, telecommunications, and the microeconomics of macroeconomic growth. Economic Development and Cultural Change, 41(1), pp.175-96.

O'Fallon, C., 2003. Linkages between infrastructure and economic growth. Pinnacle Research prepared for the Ministry of Economic Development of New Zealand, December.

Plumper, T. \& Neumayar, E., 2016,10. Robustness Check and Statistical Inference. Vienna University Economics. 
INFRASTRUCTURE INVESTMENT WITH PUBLIC-PRIVATE PARTNERSHIP (PPP) AND ECONOMIC GROWTH IN DEVELOPING COUNTRIES IN ASIA

Reddy, V.V.N., 2015. Public and Private Partnership in Infrastructure Development in India. International Journal of Business and Management Invention, pp.20-27.

Rodan., R., 1943:214. Problems of Industrialization of Eastern and SouthEastern Europe. The Economic Journal, pp.202-11.

Romer, P.M., 1987. Growth based on increasing returns due to specialization. The American Economic Review, pp.77(2), 56-62.

Rostow, W.W., 1959. The Stages of Economic Growth. The Economic History Review, New Series, pp.1-16.

Sahoo, P. \& Dash, R.K., 2012. Economic growth in South Asia: Role of infrastructure. Journal of International Trade and Economic Development, pp.217-52.

Sridhar, K.S.a.S.V., 2008. Telecommunications Infrastructure and Economic Growth: Evidence from Developing Countries. Applied Econometrics and International Development, Vol. 7, No. 2.

Stock, J.H. \& Watson, M.W., 2001. Vector Autoregression.

Straub, S., 2010:3. Infrastructure and Growth in Developing Asia. Asian Development Bank.

Trebilcock, M. \& Rosenstock., M., 2013. Infrastructure ppps in the developing world: lessons from recent experience. University of Toronto Faculty of Law.

Trebilcock, M. \& Rosenstock, M., 2013:3. Infrastructure PPPs in the Developing world: Lessons From Recent Experience.

Wooldridge, J.M., 2001. Econometric Analysis of Cross Section and Panel Data. The MIT Press: The MIT Press.

World Bank., 2016:4. The Economic Impact of Public-Private Partnerships in the Infrastructure Sector: Literature Review. World Bank.

World Bank, 1994:14. World Development Report 1994: infrastructure for development. World bank.

World Bank, 2017 June. World Bank list of economies. 
Zangoueinezhad, A..\&.A.A., 2014. How public-private partnership projects impact infrastructure industry for economic growth. International Journal of Social Economics, pp.41(10), 994-1010. 
INFRASTRUCTURE INVESTMENT WITH PUBLIC-PRIVATE PARTNERSHIP (PPP) AND ECONOMIC
GROWTH IN DEVELOPING COUNTRIES IN ASIA

\section{Appendices}

\section{Appendix 1A-Classification of Economies in the Study}

\begin{tabular}{llll}
\hline Code & \multicolumn{1}{c}{ Long Name } & \multicolumn{1}{c}{ Income Group } & \multicolumn{1}{c}{ Region } \\
\hline BGD & People's Republic of Bangladesh & Lower middle income & South Asia \\
IND & Republic of India & Lower middle income & South Asia \\
IDN & Republic of Indonesia & Lower middle income & East Asia \& Pacific \\
PAK & Islamic Republic of Pakistan & Lower middle income & South Asia \\
PHL & Republic of the Philippines & Lower middle income & East Asia \& Pacific \\
LKA & Democratic Socialist Republic of Sri & Lower middle income & South Asia \\
& Lanka & Upper middle income & East Asia \& Pacific \\
THA & Kingdom of Thailand & Upper middle income & East Asia \& Pacific \\
MYS & Malaysia & Lower middle income & East Asia \& Pacific \\
VNM & Vietnam & & \\
\hline Lower middle-income economies are those with a GNI per capita between $\$ 996$ and $\$ 3,895 ;$ \\
Upper middle-income economies are those with a GNI per capita between $\$ 3,896$ and $\$ 12,055 ;$ \\
Source:World Bank List of Economies (2017).
\end{tabular}

Appendix 1B -Asian Financial Crisis and Global Financial Crisis and Growth

Rates

\begin{tabular}{lrrrrrr}
\hline & \multicolumn{5}{c}{ Asian Economic Crisis } & \multicolumn{5}{c}{ Global Financial Crisis } \\
\hline & 1997 & 1998 & 1999 & 2007 & 2008 & 2009 \\
BGD & 2.31 & 3.02 & 2.58 & 5.77 & 4.83 & 3.89 \\
IND & 2.12 & 4.24 & 6.89 & 8.15 & 2.38 & 6.95 \\
IDN & 3.2 & -14.35 & -0.61 & 4.91 & 4.59 & 3.24 \\
MYS & 4.63 & -9.66 & 3.59 & 4.37 & 2.96 & -3.28 \\
PAK & -1.45 & 0.1 & 1.25 & 2.72 & -0.36 & 0.74 \\
PHL & 2.86 & -2.74 & 0.86 & 4.84 & 2.48 & -0.46 \\
LKA & 5.8 & 4.17 & 3.75 & 6.04 & 5.23 & 2.87 \\
VNM & 6.64 & 4.42 & 3.54 & 6.14 & 4.66 & 4.37 \\
THA & -3.89 & -8.73 & 3.38 & 4.84 & 1.19 & -1.19 \\
\hline
\end{tabular}


Appendix 2 - Initial Investment Series (fitted values) for the Sample Countries in the Base Year (1990)

\begin{tabular}{|c|c|c|c|c|c|c|c|}
\hline Observation & $\begin{array}{l}\text { Actual } \\
\text { Value }\end{array}$ & $\begin{array}{l}\text { Fitted } \\
\text { Value }\end{array}$ & $\begin{array}{l}\text { Fitted } \\
\text { Value }\end{array}$ & Observation & $\begin{array}{l}\text { Actual } \\
\text { Value }\end{array}$ & $\begin{array}{l}\text { Fitted } \\
\text { Value }\end{array}$ & $\begin{array}{l}\text { Fitted } \\
\text { Value }\end{array}$ \\
\hline & & $(\log )$ & (Level) & & & $(\log )$ & (Level) \\
\hline Bangladesh & 5.2568 & 3.8122 & 45.2503 & Sri Lanka* & 4.0163 & 5.7004 & 298.9989 \\
\hline India & 1.2383 & 3.8122 & 45.2503 & Vietnam ${ }^{*}$ & 2.1041 & 5.4381 & 230.0186 \\
\hline Indonesia & 4.6330 & 3.8122 & 45.2503 & Malaysia & 0.1743 & 3.8206 & 45.63158 \\
\hline Pakistan & 3.0267 & 3.8122 & 45.2503 & Thailand & 7.8155 & 3.8206 & 45.63158 \\
\hline Philippines & 4.9060 & 3.8122 & 45.2503 & & & & \\
\hline
\end{tabular}

*PPP investment started in the year 1993 and same year is considered as the base year.

\section{Appendix 3- Description of Variables}

\begin{tabular}{|c|c|c|}
\hline Variable & Definition & Source \\
\hline $\mathrm{Y}$ & $\begin{array}{l}\text { GDP where GDP in constant } \\
\text { PPP } 2011 \text { international \$ }\end{array}$ & $\begin{array}{l}\text { World Bank, International } \\
\text { Comparison Program database }\end{array}$ \\
\hline A & $\begin{array}{l}\text { The technological process } \\
\text { which is represented by } \\
\text { technological advancement }\end{array}$ & \\
\hline $\mathrm{K}$ & $\begin{array}{l}\text { Capital stock represented by } \\
\text { capital stock at constant } \\
\text { international Dollars PPP, } 2011\end{array}$ & IMF capital and Investment Data Set \\
\hline $\mathrm{L}$ & Total labor force at the age $15+$ & $\begin{array}{l}\text { International Labor Organization, } \\
\text { ILOSTAT database, using World } \\
\text { Bank } \\
\text { Population estimates. }\end{array}$ \\
\hline LIT & $\begin{array}{l}\text { Literacy rate, adult total } \\
(\% \text { of people ages } 15+)\end{array}$ & $\begin{array}{l}\text { United Nations Educational, } \\
\text { Scientific, and Cultural Organization } \\
\text { (UNESCO) Institute for Statistics. }\end{array}$ \\
\hline DEP & Depreciation rate & Feenstra, 2015 \\
\hline ELE & $\begin{array}{l}\text { Investment in energy with } \\
\text { private } \\
\text { Participation ( current USD) }\end{array}$ & $\begin{array}{l}\text { World Bank, Private Participation in } \\
\text { Infrastructure Project Database }\end{array}$ \\
\hline
\end{tabular}


INFRASTRUCTURE INVESTMENT WITH PUBLIC-PRIVATE PARTNERSHIP (PPP) AND ECONOMIC GROWTH IN DEVELOPING COUNTRIES IN ASIA

\begin{tabular}{cll}
\hline TEL & $\begin{array}{l}\text { Investment in } \\
\text { telecommunication with private } \\
\text { Participation (currentUSD) }\end{array}$ & $\begin{array}{l}\text { World Bank, Private Participation in } \\
\text { Infrastructure Project Database }\end{array}$ \\
TRA & $\begin{array}{l}\text { Investment in transport with } \\
\text { private }\end{array}$ & $\begin{array}{l}\text { World Bank, Private Participation in } \\
\text { Infrastructure Project Database }\end{array}$ \\
Participation (currentUSD) & World Bank, Private Participation in \\
WATSAN & $\begin{array}{l}\text { Investment in water and } \\
\text { sanitation with private } \\
\text { Participation (currentUSD) }\end{array}$ & Infrastructure Project Database \\
\hline
\end{tabular}

Appendix 4- Description of Variables

\begin{tabular}{|c|c|c|c|c|c|}
\hline \multicolumn{2}{|c|}{ Variable name } & \multicolumn{4}{|l|}{ Description } \\
\hline \multicolumn{2}{|c|}{ GDP } & \multicolumn{4}{|c|}{ Constant Gross Domestic Production } \\
\hline \multicolumn{2}{|c|}{ INFP } & \multicolumn{4}{|c|}{$\begin{array}{l}\text { Infrastructure stock generated by Private public participation of } \\
\text { infrastructure }\end{array}$} \\
\hline \multicolumn{2}{|c|}{ INFN } & \multicolumn{4}{|c|}{$\begin{array}{l}\text { Infrastructure Stock without Private public participation } \\
\text { investment in infrastructure }\end{array}$} \\
\hline \multirow{2}{*}{\multicolumn{2}{|c|}{$\begin{array}{c}\text { LIT } \\
\text { DU98 }\end{array}$}} & \multicolumn{4}{|l|}{ Literacy rate } \\
\hline & & \multicolumn{4}{|c|}{ Asian Economic crisis } \\
\hline \multicolumn{6}{|c|}{ Appendix 5-Correlation Test } \\
\hline & GDP & INFP & LAB & LIT & INFN \\
\hline GDP & \multicolumn{5}{|l|}{1.0000} \\
\hline INFP & 0.3319 & \multicolumn{4}{|l|}{1.0000} \\
\hline LAB & 0.8264 & 0.1312 & 1.0000 & & \\
\hline LIT & -0.0597 & 0.2266 & -0.3505 & 1.0000 & \multirow[b]{2}{*}{1.0000} \\
\hline INFN & 0.9077 & 0.2509 & 0.7313 & -0.0996 & \\
\hline
\end{tabular}


P.J. ATAPATTU

\section{Appendix 6- Unit Root Test}

\begin{tabular}{lrrrrrr}
\hline \multicolumn{1}{c}{ Variable } & \multicolumn{1}{l}{ Level } & \multicolumn{1}{l}{ Form } & & \multicolumn{1}{l}{ First } & Difference & \\
& & & & & & \\
& LLC & IPS & ADF & LLC & IPS & ADF \\
GDP & 2.6489 & 5.7315 & 5.8618 & -5.09686 & -4.59771 & 53.6696 \\
Probability & $(0.9960)$ & $(1.0000)$ & $(0.9967)$ & $(0.0000)$ & $(0.0000)$ & $(0.0000)$ \\
& & & & & & \\
INFP & -38.1232 & -2.3402 & -23.2122 & & & \\
Probability & $(0.0000)$ & $(0.0096)$ & $(0.0000)$ & & & \\
LAB & -3.4325 & 0.1538 & 24.0596 & -3.98113 & -5.21673 & 62.5716 \\
Probability & $(0.0003)$ & $(0.5611)$ & $(0.1531)$ & $(0.0000)$ & $(0.0000)$ & $(0.0000)$ \\
LIT & & & & & & \\
Probability & -3.3711 & 0.1468 & 17.1383 & -2.7594 & -5.0986 & 56.3929 \\
& $(0.0004)$ & $(0.5584)$ & $(0.3767)$ & $(0.0029)$ & $(0.0000)$ & $(0.0000)$ \\
INFN & -3.4698 & -0.4916 & 33.2179 & -3.0357 & -3.5269 & 45.8138 \\
Probability & $(0.0003)$ & $(0.3115)$ & $(0.0157)$ & $(0.0012)$ & $(0.0002)$ & $(0.0003)$ \\
& & & & & &
\end{tabular}

LLC - $\quad$ Levin, Lin \& Chu testIPS - Im, Pesaran and Shin W-statistic

ADF - Fisher Chi-square

Appendix 7A - Cointegration Rank Test (Trace)

\begin{tabular}{|c|c|c|c|c|}
\hline No. of CE(s)Hypothesized & Eigenvalue & Statistic Trace & $\begin{array}{l}0.05 \\
\text { Critical Value } \\
\end{array}$ & Prob.** \\
\hline ivuile & 0.7417 & 295.86 & 69.81 & 0.0001 \\
\hline At most 1 & 0.0532 & 21.00 & 47.85 & 0.9845 \\
\hline At most 2 & 0.0306 & 9.88 & 29.79 & 0.9819 \\
\hline At most 3 & 0.0148 & 3.56 & 15.49 & 0.9353 \\
\hline At most 4 & 0.0026 & 0.53 & 3.84 & 0.4630 \\
\hline
\end{tabular}


INFRASTRUCTURE INVESTMENT WITH PUBLIC-PRIVATE PARTNERSHIP (PPP) AND ECONOMIC GROWTH IN DEVELOPING COUNTRIES IN ASIA

Appendix 7B- Cointegration Rank Test (Maximum Eigenvalue)

\begin{tabular}{|c|c|c|c|c|}
\hline No. of CE(s)Hypothesized & $\begin{array}{l}\text { Max-Eigenval גe } \\
\text { Eigen }\end{array}$ & $\begin{array}{l}0.05 \\
\text { Statistic } \\
\end{array}$ & Critical Value & Prob.** \\
\hline None * & 0.7417 & 274.8594 & 33.8768 & 0.0000 \\
\hline At most 1 & 0.0532 & 11.1183 & 27.5843 & 0.9623 \\
\hline At most 2 & 0.0306 & 6.3210 & 21.1316 & 0.9757 \\
\hline At most 3 & 0.0148 & 3.0287 & 14.2646 & 0.9448 \\
\hline At most 4 & 0.0026 & 0.5386 & 3.8414 & 0.4630 \\
\hline
\end{tabular}

Appendix 8- Results VAR Model

Dependent Variable: GDP

\begin{tabular}{|c|c|c|c|c|c|c|}
\hline Model & LMC & & UMC & & Developin & Countries \\
\hline Variable & VAR & $\begin{array}{l}\text { Wald Test } \\
\text { probability }\end{array}$ & VAR & $\begin{array}{l}\text { Wald Test } \\
\text { probability }\end{array}$ & VAR & $\begin{array}{l}\text { Wald Test } \\
\text { probability }\end{array}$ \\
\hline $\mathrm{D}(\operatorname{INFP}(-1))$ & $\begin{array}{l}0.0017 \\
(0.0020) \\
{[0.8537]}\end{array}$ & & $\begin{array}{l}-0.0297 \\
(0.0259) \\
{[-1.1458]}\end{array}$ & & $\begin{array}{l}0.0033 \\
(0.0022) \\
{[1.4976]}\end{array}$ & \\
\hline Probability & (0.3935) & & $(0.2535)$ & & $(0.1346)$ & \\
\hline $\mathrm{D}(\operatorname{INFP}(-2))$ & $\begin{array}{l}7.4988 \\
(0.0019) \\
{[0.0381]} \\
(0.9696)\end{array}$ & & $\begin{array}{l}-0.0073 \\
(0.0120) \\
{[-0.6130]} \\
(0.5407)\end{array}$ & & $\begin{array}{l}0.0011 \\
(0.0020) \\
{[0.5465]} \\
(0.5848)\end{array}$ & \\
\hline $\begin{array}{l}\mathrm{D}(\mathrm{INFP}(-1)) \mathrm{D}(\mathrm{INFP} \\
(-2))\end{array}$ & & 0.6938 & & 0.4397 & & 0.2735 \\
\hline $\mathrm{D}(\mathrm{INF}(-1))$ & $\begin{array}{l}0.0470 \\
(0.0743) \\
{[0.6334]}\end{array}$ & & $\begin{array}{l}-0.0575 \\
(0.2945) \\
{[-0.1953]}\end{array}$ & & $\begin{array}{l}0.0836 \\
(0.0776) \\
{[1.0778]}\end{array}$ & \\
\hline Probability & (0.5267) & & $(0.8454)$ & & $(0.2814)$ & \\
\hline $\mathrm{D}(\mathrm{INF}(-2))$ & $\begin{array}{l}0.0244 \\
(0.0737) \\
{[0.3311]}\end{array}$ & & $\begin{array}{l}0.0876 \\
(0.2793) \\
{[0.3136]}\end{array}$ & & $\begin{array}{l}0.0090 \\
(0.0776) \\
{[0.1163]}\end{array}$ & \\
\hline $\begin{array}{l}\text { Probability } \\
\text { D(INF (-1)) D( INF } \\
(-2))\end{array}$ & $(0.7406)$ & 0.8038 & $(0.7542)$ & 0.1029 & $(0.9074)$ & 0.7637 \\
\hline $\mathrm{D}(\mathrm{LAB}(-1))$ & $\begin{array}{l}-0.0678 \\
(0.1269) \\
{[-0.5348]} \\
(0.5929)\end{array}$ & & $\begin{array}{l}0.8329 \\
(0.4317) \\
{[1.9292]} \\
(0.0554)^{c}\end{array}$ & & $\begin{array}{l}0.0786 \\
(0.1290) \\
{[0.6096]} \\
(0.5422)\end{array}$ & \\
\hline
\end{tabular}


P.J. ATAPATTU

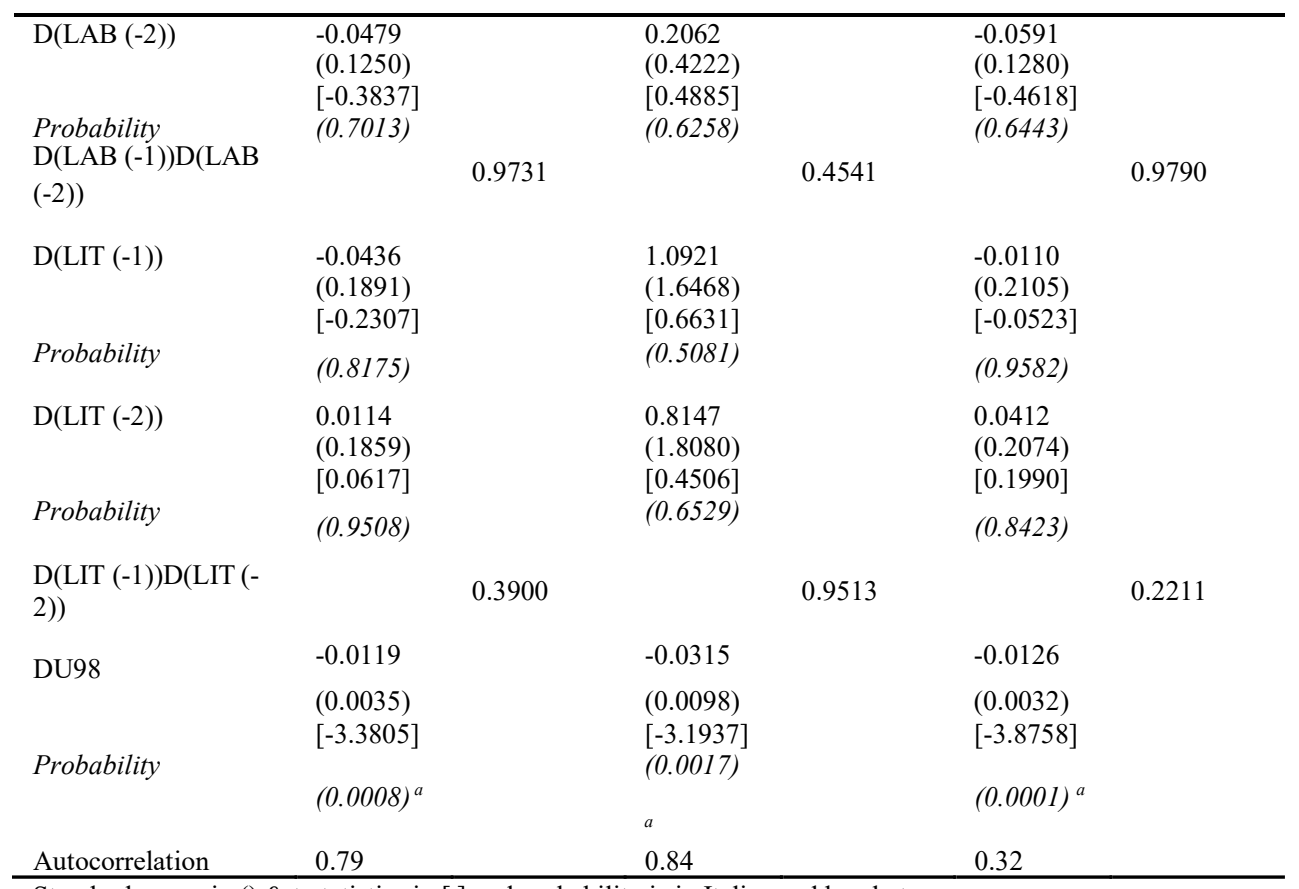

Standard errors in () \& t-statistics in [ ] and probability is in Italics and brackets. 
INFRASTRUCTURE INVESTMENT WITH PUBLIC-PRIVATE PARTNERSHIP (PPP) AND ECONOMIC GROWTH IN DEVELOPING COUNTRIES IN ASIA

Appendix 9- Robustness Test Results (Robust Least Squares, M-estimation)

\begin{tabular}{|c|c|c|c|}
\hline Variable ${ }^{\text {Model }}$ & ACFEdu98 & LMIFEdu98 & UMIFEdu98 \\
\hline PINF & $\begin{array}{l}0.0573^{\mathrm{a}} \\
(0.0108)\end{array}$ & $\begin{array}{l}0.0395^{\mathrm{a}} \\
(0.0068)\end{array}$ & $\begin{array}{l}0.0207^{\mathrm{a}} \\
(0.0090)\end{array}$ \\
\hline NINF & $\begin{array}{l}0.3474^{\mathrm{a}} \\
(0.0180)\end{array}$ & $\begin{array}{l}0.3410^{\mathrm{a}} \\
(0.0279)\end{array}$ & $\begin{array}{l}0.3018^{\mathrm{a}} \\
(0.0436)\end{array}$ \\
\hline LAB & $\begin{array}{l}0.6255^{\mathrm{a}} \\
(0.0204)\end{array}$ & $\begin{array}{l}0.6169^{\mathrm{a}} \\
(0.0327)\end{array}$ & $\begin{array}{l}1.1545^{\mathrm{a}} \\
(0.0279)\end{array}$ \\
\hline LIT & $\begin{array}{l}0.5711^{\mathrm{a}} \\
(0.0557)\end{array}$ & $\begin{array}{l}0.8138^{a} \\
(0.0525)\end{array}$ & $\begin{array}{l}2.2077^{c} \\
(0.7307)\end{array}$ \\
\hline Du98 & $\begin{array}{l}-0.0034^{c} \\
(0.0387)\end{array}$ & $\begin{array}{l}-0.0076^{\mathrm{c}} \\
(0.0391)\end{array}$ & $\begin{array}{l}-0.0598^{c} \\
(0.0196)\end{array}$ \\
\hline $\mathrm{R}^{2}$ & 0.84 & 0.86 & 0.76 \\
\hline Adjusted $\mathrm{R}^{2}$ & 0.83 & 0.85 & 0.73 \\
\hline $\begin{array}{l}\text { Number Of } \\
\text { Observations }\end{array}$ & 214 & 168 & 50 \\
\hline
\end{tabular}

